\title{
The 9th International Conference on Life Cycle Management 2019_Poznań, Poland, 1-4 September 2019 (www.lcm2019.org)
}

\author{
Zbigniew Stanislaw Klos ${ }^{1} \cdot$ Joanna Kulczycka ${ }^{2} \cdot$ Anna Lewandowska $^{3} \cdot$ Stefan Trzcielinski ${ }^{1}$
}

Received: 3 November 2018 / Accepted: 6 November 2018 / Published online: 12 November 2018

(C) The Author(s) 2018

Keywords Conference sessions $\cdot$ Life cycle management $\cdot$ Sustainability

\section{Invitation}

Poznań University of Technology in collaboration with Poznań University of Economics, Mineral and Energy Economy Research Institute in Kraków as well as with Solaris Bus and Coach S.A., invites you to participate in the 9th Conference on Life Cycle Management "Towards Sustainable Future. Current Challenges and Prospects in the Life Cycle Management (LCM 2019)" on September 1-4, 2019.

After successful previous events in Bordeaux (2015) and Luxembourg (2017), where over 650 participants from about 40 countries discussed the current issues connected with LCM, the next conference will be held for the first time in the Central-Eastern European country-Poland, in Poznań, a city located in the mid-western part of Poland. Poznan is the capital of Wielkopolska (Great Poland), a region known for its history (first capitals of Poland were located here), developed industry and services (the largest international trade fair in Central and Eastern Europe is held here) and efficient agriculture. Poznan is not only a center of business activity but also a place of intensive academic life. We hope that our location will not only be a unique opportunity to gather well-known and experienced LCM participants, but will also attract new ones from other regions of the world.

Responsible editor: Mary Ann Curran

Anna Lewandowska

anna.lewandowska@ue.poznan.pl

Poznan University of Technology, Poznan, Poland

2 MEERI Polish Academy of Sciences, Cracow, Poland

3 Poznan University of Economics and Business, Poznan, Poland

\section{Theme}

The central assumption of all LCM conferences is to bring together participants from the world of science with representatives of enterprises and institutions supporting economic activity. This allows the conference topics to be more focused on the practical aspects of product life cycle management and to enable effective networking. We have decided to base the conference program on a five-theme structure. The themes represent different objects and are focused on sustainability and LCM practices related to (1) products, (2) technologies, (2) organizations, (4) markets and policy, and (5) methodological solutions. All conference sessions will be placed in these five themes. During call for abstracts, authors will be asked to submit their abstracts dedicated to one theme and later to one of the sessions belonging to this theme.

A list of topics for the conference sessions will be announced during call for abstracts. Discussed will be different issues, among others:

- Design and innovation of complex product systems and services, design for sustainability;

- LCM for different objects: electric and electronic products, agri-food products, sustainable chemicals and materials, plastic products, non-ferrous metals, ferrous metals, and construction sector;

- Sustainable health management and environmental performance of health services,

- Sustainable mobility and transport;

- Emerging technologies, road-mapping sustainable energy technologies and systems;

- Biomass conversion and biofuels-technologies and LCA;

- Negative emission technologies and positive environmental impacts; 
- Life cycle thinking from the organization's purchasing point of view;

- Success factors for embedding life cycle management into existing business practices;

- Life cycle manager on the labor market - from sustainability oriented education to professional career;

- Sustainable product portfolio-good practice and developing tools for PP management;

- Life cycle approaches to sustainable regional development;

- Designing sustainable lifestyles - from social structure to personal choices;

- Addressing marine litter within life cycle assessment and management;

- Circular economy and LCM - challenges for development of life cycle inventory databases.

\section{Important dates}

The most important dates of the conference are the following:

- A call for abstracts - 15 November, with the deadline till 31 December 2018

- A call for early bird registration-till 20 May 2019.

- A call for registration-till 31 July 2019.

- A call for late registration-till 20 August 2019.
For further information, visit the conference website www. lcm2019.org or contact 1cm2019@put.poznan.pl.

See you in Poznań, Poland, at the beginning of September 2019.

Publisher's Note Springer Nature remains neutral with regard to jurisdictional claims in published maps and institutional affiliations.

Open Access This article is distributed under the terms of the Creative Commons Attribution 4.0 International License (http:// creativecommons.org/licenses/by/4.0/), which permits unrestricted use, distribution, and reproduction in any medium, provided you give appropriate credit to the original author(s) and the source, provide a link to the Creative Commons license, and indicate if changes were made. 